\title{
Iranian EFL learners' attitude towards the use of WBLL approach in writing
}

\author{
Mashhadizadeh, Davood $\measuredangle$ \\ Sobhe Sadegh Institute of Higher Education, Isfahan, Iran (Davood.mashhadizadeh@yahoo.com) \\ Rezvani, Ehsan \\ Sobhe Sadegh Institute of Higher Education, Isfahan, Iran (Rezvani_ehsan_1982@yahoo.com)
}

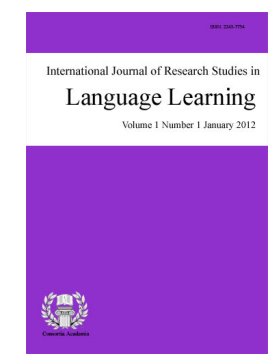

ISSN: $2243-7754$ Online ISSN: 2243-7762

OPEN ACCESS

\section{Abstract}

World Wide Web has improved the capabilities of Computer Assisted Language Learning (CALL) by empowering learners to refine their learning ways themselves. The current study was aimed at investigating Iranian EFL learners' attitude towards the use of a WBLL approach to improve the production of lexical and grammatical collocations in writing. A website, http://olrc.ir, was established to help with planning the course activities, and preparing the materials. Nine classes were randomly selected from High Intermediate EFL courses held in ACECR Language Center. A total of 78 students participated in the study after administering the exclusion criteria. The materials used in the main WBLL course included links to online corpora, an online dictionary, an online translator tool, as well as specifically designed materials for the writings. According to the results of the current study, learners' attitude towards the WBLL approach was positive and favorable in the areas of the helpfulness of the approach, and improvement in their confidence and writing proficiency, as well as the sub-field of word phrase. Learners also reflected a preference for the online collocation dictionary over the online corpus, as the online dictionary was easier to manage in numerous ways. Moreover, learners' attitude towards using the approach for further assignments, apart from personal English writings, was positive. Generally, it was revealed that the shift to WBLL approach is mostly welcomed by the learners, especially when the tools and materials are easy enough to be handled and analyzed.

Keywords: WBLL; learner attitude; concordance; online collocations dictionary; writing 


\section{Iranian EFL learners' attitude towards the use of WBLL approach in writing}

\section{Introduction}

World Wide Web has improved the capabilities of Computer Assisted Language Learning (CALL) by empowering learners to refine their learning ways themselves and providing them with an easily accessed on-line database of various resources (Felix, 2001; Murray \& McPherson, 2004; Son, 2005). In addition, Web Based Language Learning (WBLL) has the capability to boost learner motivation and involve learners in an authentic and interactive language experience (Gruber-Miller \& Benton, 2001; Kung \& Chuo, 2002; Mosquera, 2001). In addition, Son (2007) reports on learners' backgrounds, learning styles, strategies and experiences in WBLL environments. Having this diversity in mind, many researchers have conducted studies on students' attitudes towards Internet-based activities to help understand ways of applying Internet resources to enhance language learning. For example, Stepp- Greany (2002) investigated student perceptions on the use of multimedia for language instruction in Spanish classes. Moreover, Robert Ayres (2010) stated that the evaluation and effectiveness of language learning materials and tasks, from the viewpoint of the learners, is also a key part in the development of materials in WBLL approach.

Studies indicate that both Iranian teachers and students have positive attitudes towards the integration of technology into foreign language courses (Rahimi \& Hosseini K., 2011; Dashtestani, 2012; Talebinezhad \& Aziz Abarghoui, 2013; Jalali \& Dousti, 2014; Amirsheibani \& Iraji, 2014). In the study by Amirsheibani and Iraji (2014), the attitude of 101 English language teachers towards the effect of CALL on teaching writing was investigated. It was revealed that Iranian teachers have a positive attitude towards using CALL. Moreover, Talebinezhad and Aziz Abarghoui (2013) concluded that most high school students had positive perceptions of CALL and its use for EFL receptive skills. In another study done by Nam, D. (2010), the attitude of learners towards the actual use of thesaurus and online corpora was investigated. However, few studies in Iran have focused on the learners' attitude towards the use of WBLL approach in particular. Most studies include rather traditional aspects of CALL, involving the use of multimedia accessed through CD-ROMs and computers which were mainly tasked to play audio tracks or execute dictionary software. Studying the learners' perspective on a whole Web-based syllabus has been of little interest to the researchers in the field. Hence, an investigation of the learners' attitude towards the WBLL approaches seems necessary.

The current study was aimed at investigating Iranian EFL learners' attitude towards the use of a WBLL approach, which in turn was designed to improve the production of lexical and grammatical collocations in writing.

\subsection{Research Objectives}

The current study was an attempt to shed light on the concept of learner attitude towards WBLL approach in the setting of collocation production in writing paragraphs. The main focus of this study was to investigate Iranian learners' perspective on the efficacy of the approach, as well as their reaction to the tools, and eventually their further using the materials presented in the approach for future assignments. In order to address the research objectives, three main research questions were raised:

$>\quad$ What is the Iranian EFL learners' attitude towards the WBLL approach?

$>$ What is the Iranian EFL learners' attitude towards the tools used in the WBLL approach?

$>\quad$ What is the Iranian EFL learners' attitude towards the use of materials and tools presented in the WBLL approach for future assignments? 


\section{Methods and Materials}

\subsection{Setting}

A website, http://olrc.ir (Online Language Research Center), was established prior to the onset of the research to help with planning the course activities, and preparing the materials for the students' writings. These activities included the entire needed vocabulary glossary; collocation lists, topics, as well as links to an online collocation dictionary and online corpora, hence providing a WBLL environment for the students. In order to maximize the WBLL experience, Moodle was chosen as an educational interface for the website to allow for the flexibility needed by a teacher to plan and design a WBLL course and create assignments, glossaries, chat forums, quizzes, and feedback sheets.

\subsection{Participants}

In order to conduct the study, nine classes were randomly selected from High Intermediate EFL courses held in ACECR Language Center (Known publicly as Jahad-e-Daneshgahi). The number of students in the classes summed up to 108 , out of which a total of 78 students participated in the study after administering the exclusion criteria. The exclusion criteria included the prior encounter with the selected materials, any attitude due to prior use of WBLL approach, and absence of the Internet support. The pre-questionnaire helped collect the demographic information of the participants. Table 1 presents subjects' age.

Table 1

Participants' Age

\begin{tabular}{lccccc}
\hline \multicolumn{5}{c}{ Age } & \\
\hline & $\mathrm{N}$ & Minimum & Maximum & Mean & SD \\
\hline Age & 78 & 16.00 & 53.00 & 30.23 & 9.34 \\
Valid N (listwise) & 78 & & & & \\
\hline
\end{tabular}

Participants typically had already studied English for 1 to 2 years (34\%), and had taken at least 1 to 3 courses at the center (57\%). They normally wrote academic English about an average of 2.9 hours in a week. Other areas of writing in English (e-mails, and so) took their time an average of 3.7 hours in a week. Generally speaking, they liked using computer $(96.15 \%)$ and had access to the Internet. However, just 18 leaners out of the 78 participants in the study $(23.08 \%$ ) had already used the Internet as a reference for composing essays, three of whom (11.54\%) had already heard about (but not used) more sophisticated means of WBLL approach (such as the corpora or online collocation dictionaries).

\subsection{Materials}

The materials used in the main WBLL course included links to online corpora, an online dictionary, an online translator tool, as well as designed materials such as a guide to help learners with materials use and course design, a set of writing activities with selected words and topics. Inevitably, an interface was chosen for the website which allowed submission and grading of writings, commenting, sharing ideas, asking questions and posting answers, timing, automation, basic analysis, and a lot more. However, the second questionnaire, referred to as post-study survey, mostly focused on the reactions of the learners to the WBLL approach, their perception of improvement in writing, the usefulness of the WBLL tools, and their outside assignment use of the tools introduced in the approach. It contained 31 questions divided into three sections.

\subsection{Procedure}

The whole project took almost four months. The course of action for the main procedure lasted almost three months, and the delayed post-test took place one month after the post-test. Before the onset of the project, all the 
Mashhadizadeh, D., \& Rezvani, E.

participants were asked to log onto their profiles to take the pre-study survey. Upon completing the questionnaire, learners were fully instructed (in 5 training sessions) on the use of corpus concordancer, the online dictionary, the online translator, and the website interface. Then, they were led to follow their writing assignments at home and they were referred to WBLL resources available on the website as a source of assistance to achieve maximum native accuracy. In the meantime, no other form of help, except for the feedback, was given by the teacher. Students were allowed to ask their questions regarding the use of materials or the interface; however, in order to help them with their writings, they were referred back to the materials and the online resources. Students wrote paragraphs consulting the corpora and all the other WBLL materials provided on the website as needed.

For each task, they could save and modify their drafts online, and the teacher was also able to see the progress. At the end, the learners had to submit their final draft by a deadline, after which their assignment was graded by the teacher, and a comment including the corrected submission was returned to the learner for each submitted assignment. As the students submitted their final assignment, the teacher called upon the learners to take the post-study survey. Finally, after a period of one month, the students were again asked to participate in a session at the same computer site to take the delayed post-test.

\section{Analysis and Results}

\subsection{Learners' attitude towards their proficiency}

The pre-study survey collected information on the learners' attitude towards their proficiency in the areas of writing, and general English as well as computers. According to the pre-questionnaire, half of the participants (50\%) perceived their overall English proficiency as good, $34 \%$ as fair, and $15 \%$ as poor (Mean 2.34, SD 0.7). In the area of English Academic writing, 50\% of the learners perceived their proficiency as poor, $23 \%$ as fair, $23 \%$ as good, and just 3\% as excellent (Mean 1.8, SD 0.9). However, in the field of English writing for other purposes, $19 \%$ of the participants found their proficiency as poor, $26 \%$ as fair, $46 \%$ as good, and $7 \%$ as excellent (Mean 2.4, SD 0.9). Considering the knowledge of computers, $11 \%$ of the learners described their proficiency level as poor, $7 \%$ as fair, $38 \%$ as good, and $42 \%$ as excellent (Mean 3.1, SD 0.9). The summary of all the data on learners' attitude towards their proficiency is given in table 2 .

Table 2

Learners' Attitude towards their English Language Proficiency

\begin{tabular}{lcccccc}
\hline & Poor & Fair & Good & Excellent & Mean & SD \\
\hline Overall English Proficiency & 12 & 27 & 39 & 0 & 2.35 & 0.75 \\
(Percentage) & $15.38 \%$ & $34.61 \%$ & $50 \%$ & 0 & & \\
English academic writing proficiency & 39 & 18 & 18 & 3 & 1.81 & 0.94 \\
(Percentage) & $50 \%$ & $23.07 \%$ & $23.07 \%$ & $3.84 \%$ & & \\
English writing proficiency in other areas & 15 & 21 & 36 & 6 & 2.42 & 0.90 \\
(Percentage) & $19.23 \%$ & $26.92 \%$ & $46.15 \%$ & $7.69 \%$ & 3.12 & 0.99 \\
knowledge of computers in general & 9 & 6 & 30 & 33 & 3.12 \\
(Percentage) & $11.53 \%$ & $7.69 \%$ & $38.46 \%$ & $42.30 \%$ & & \\
\hline
\end{tabular}

\subsection{Learners' Attitude towards using the WBLLApproach}

According to the post-study survey, learners had perceived an increase in their confidence level, as the mean score for this item is 4.26 with a standard deviation of around 0.72 . More precisely, 33 participants strongly agree $(42.3 \%)$ and 33 participants $(42.3 \%)$ agree that they feel more confident in writing in English after the WBLL course. Moreover, the mean score of 4.23 for both the second and third items showed that it was helpful for the learners to write the tasks using the corpus and the online collocations dictionary. In the case of dealing with the preposition usage, using the online collocation dictionary was a bit more helpful to the learners than the online corpus, as the mean scores for the two are 4.34 and 4.30, respectively. However, in the field of word 
Iranian EFL learners' attitude towards the use of WBLL approach in writing

phrase usage, the corpus showed more promising results as its mean score was 4.11 compared to the mean score of 2.96 for the online collocations dictionary, which in turn revealed the answers for the effectiveness of the online collocation dictionary for word phrase usage were rather undecided (45 participants, 57.69\%). In general, 27 participants $(34.61 \%)$ strongly agreed that writing with WBLL approach had increased their writing proficiency in English, whereas 42 participants (53.84\%) agreed and 9 (11.53\%) did not take any position.

Table 3 presents the data on learners' attitude towards the WBLL approach. Note that in the "mean score" column, any mean score above 3 shows a positive trend, as the scores start from 1 (strongly disagree) to 5 (strongly agree).

Table 3

Learners' Attitude towards the WBLL Approach

\begin{tabular}{|c|c|c|c|c|c|c|c|}
\hline & $\begin{array}{l}\text { Strongly } \\
\text { disagree }\end{array}$ & Disagree & Undecided & Agree & $\begin{array}{l}\text { Strongly } \\
\text { agree }\end{array}$ & Mean & $\mathrm{SD}$ \\
\hline $\begin{array}{l}\text { The WBLL Course has increased my } \\
\text { confidence in writing in English }\end{array}$ & 0 & 0 & 12 & 33 & 33 & 4.26 & 0.72 \\
\hline (Percentage) & $0 \%$ & $0 \%$ & $15.38 \%$ & $42.30 \%$ & $42.30 \%$ & & \\
\hline $\begin{array}{l}\text { It was helpful to write the tasks by } \\
\text { using the corpus. }\end{array}$ & 0 & 0 & 6 & 48 & 24 & 4.23 & 0.58 \\
\hline (Percentage) & $0 \%$ & $0 \%$ & $7.69 \%$ & $61.53 \%$ & $30.76 \%$ & & \\
\hline $\begin{array}{l}\text { It was helpful to write the tasks by } \\
\text { using the online collocation } \\
\text { dictionary. } \\
\text { (Percentage) }\end{array}$ & $0 \%$ & $3.84 \%$ & $7.69 \%$ & $50 \%$ & $38.46 \%$ & 4.23 & 0.76 \\
\hline $\begin{array}{l}\text { Using the corpus was helpful for } \\
\text { dealing with the preposition usage in } \\
\text { my writing. } \\
\text { (Percentage) }\end{array}$ & $0 \%$ & $3.84 \%$ & $7.69 \%$ & $42.30 \%$ & $46.15 \%$ & 4.30 & 0.78 \\
\hline $\begin{array}{l}\text { Using the online collocation } \\
\text { dictionary was helpful for dealing } \\
\text { with the preposition usage in my } \\
\text { writing. } \\
\text { (Percentage) }\end{array}$ & $0 \%$ & $0 \%$ & $7.69 \%$ & $50 \%$ & $42.30 \%$ & 4.34 & 0.62 \\
\hline $\begin{array}{l}\text { Using the corpus was helpful for } \\
\text { dealing with the word phrase usage in } \\
\text { my writing. } \\
\text { (Percentage) }\end{array}$ & $0 \%$ & $0 \%$ & $15.38 \%$ & $57.69 \%$ & $26.92 \%$ & 4.11 & 0.65 \\
\hline $\begin{array}{l}\text { Using the online collocation } \\
\text { dictionary was helpful for dealing } \\
\text { with the word phrase usage in my } \\
\text { writing. } \\
\text { (Percentage) }\end{array}$ & $3.84 \%$ & $19.23 \%$ & $57.69 \%$ & $15.38 \%$ & $3.84 \%$ & 2.96 & 0.82 \\
\hline $\begin{array}{l}\text { In general, writing with WBLL } \\
\text { approach increased my writing } \\
\text { proficiency in English. } \\
\text { (Percentage) }\end{array}$ & 0 & 0 & $11.53 \%$ & $53.84 \%$ & $34.61 \%$ & 4.23 & 0.65 \\
\hline
\end{tabular}

\subsection{Learners' Attitude towards the Tools}

Based on the results from the post-study survey, participants showed a slight preference for the online collocation dictionary to the online corpus as the tool. The corpus searching technique was not easy to learn rather than that of the online collocation dictionary (mean score of 1.96), and the corpus did not excel the other online reference tools such as the collocation dictionary in "finding the appropriate vocabulary", as 39 participants $(50 \%)$ answered the question "undecided" (mean score of 2.65). However, the learners agreed that the time and effort needed to analyze the corpus output decreased as they used the corpus (mean score of 3.92). Participants favored the corpus output as they agreed that the output from the corpus provided enough information on the usage of the vocabulary with the mean score of 4.34 , compared to the mean score of 4.23 for the output from the online collocation dictionary. 
Mashhadizadeh, D., \& Rezvani, E.

The real texts from the corpus were not easy to understand and use in writing (mean score of 1.84). Furthermore, in the case of getting the needed information, participants favored the online collocation dictionary with the mean score of 4.19 , compared to the mean score of 4.07 for the corpus. Significantly, analyzing the output from the online collocation dictionary was easier than the output from the corpus, with a mean score of 4.30 versus 2 respectively. A total of 33 participants (42.30\%) strongly disagreed with having difficulty using the online corpus and/or the online collocation dictionary due to limited access to computers (mean score of 2.46), which leaves the time and effort spent on analyzing the output from the tools as a source of problem with a mean score of 3.96 .

Using the corpus and the online collocations dictionary, the learners reflected making meaningful and noticeable improvements in their writing in learning to use correct grammar (mean score of 4.11) and use vocabulary appropriately (mean score of 4.38). However, the participants reflected doubt on making meaningful and noticeable improvements in their writing in the case of learning the meaning of the vocabulary (mean score of 2.73 ) with 48 participants $(61.53 \%)$ undecided and 21 participants $(26.92 \%)$ disagreeing with the idea. Writing organization (mean score of 2.15) was the other area of poor improvement as 21 participants $(26.92 \%)$ chose undecided, 27 participants $(34.61 \%)$ disagreed, and 24 participants $(30.76 \%)$ strongly disagreed with the concept.

Over all, the participants referred to the corpus and/or the online collocation dictionary as useful resources for their English proficiency improvement with a mean score of 4.23 out of 5 . Table 4 briefly presents the information on the learners' attitude towards the WBLL tools.

\section{Table 4}

Learners' Attitude towards the Tools

\begin{tabular}{|c|c|c|c|c|c|c|c|}
\hline & $\begin{array}{l}\text { Strongly } \\
\text { disagree }\end{array}$ & Disagree & Undecided & Agree & $\begin{array}{c}\text { Strongly } \\
\text { agree }\end{array}$ & $\begin{array}{l}\text { Mean } \\
\text { score (out } \\
\text { of 5) }\end{array}$ & SD \\
\hline $\begin{array}{l}\text { The corpus searching technique was } \\
\text { easier to learn than other references, } \\
\text { such as the collocation dictionary } \\
\text { (Percentage) }\end{array}$ & $30.76 \%$ & $50 \%$ & $11.53 \%$ & $7.69 \%$ & $0 \%$ & 1.96 & 0.87 \\
\hline $\begin{array}{l}\text { The corpus was useful for finding } \\
\text { appropriate words than other } \\
\text { references, such as the collocation } \\
\text { dictionary. } \\
\text { (Percentage) }\end{array}$ & $7.69 \%$ & $30.76 \%$ & $50 \%$ & $11.53 \%$ & $0 \%$ & 2.65 & 0.79 \\
\hline $\begin{array}{l}\text { The time and effort I spent on } \\
\text { analyzing the concordancer output } \\
\text { reduced as I used the corpus. } \\
\text { (Percentage) }\end{array}$ & 0 & $7.69 \%$ & $7.69 \%$ & $69.23 \%$ & $15.38 \%$ & 3.92 & 0.74 \\
\hline $\begin{array}{l}\text { The corpus output provided enough } \\
\text { information that I needed to find out } \\
\text { the usage of the vocabulary. } \\
\text { (Percentage) }\end{array}$ & $0 \%$ & $3.84 \%$ & $3.84 \%$ & $46.15 \%$ & $46.15 \%$ & 4.34 & 0.74 \\
\hline $\begin{array}{l}\text { The online collocation dictionary } \\
\text { output provided enough information } \\
\text { that I needed to find out the usage of } \\
\text { the vocabulary. } \\
\text { (Percentage) }\end{array}$ & $0 \%$ & $0 \%$ & $3.84 \%$ & $69.23 \%$ & $26.92 \%$ & 4.23 & 0.51 \\
\hline $\begin{array}{l}\text { The real texts in the corpus are easy } \\
\text { to understand to use in writing. } \\
\text { (Percentage) }\end{array}$ & $\begin{array}{c}36 \\
46.15 \%\end{array}$ & $\begin{array}{c}27 \\
34.61 \%\end{array}$ & $11.53 \%$ & $3.84 \%$ & $\begin{array}{c}3 \\
3.84 \% \\
\end{array}$ & 1.84 & 1.04 \\
\hline $\begin{array}{l}\text { When I searched for information in } \\
\text { the corpus, I got the information that I } \\
\text { needed. } \\
\text { (Percentage) }\end{array}$ & $0 \%$ & $0 \%$ & $7.69 \%$ & $76.92 \%$ & $15.38 \%$ & 4.07 & 0.48 \\
\hline
\end{tabular}


Iranian EFL learners' attitude towards the use of WBLL approach in writing

Table 4 ... continued

\begin{tabular}{|c|c|c|c|c|c|c|c|}
\hline & $\begin{array}{l}\text { Strongly } \\
\text { disagree }\end{array}$ & Disagree & Undecided & Agree & $\begin{array}{l}\text { Strongly } \\
\text { agree }\end{array}$ & $\begin{array}{l}\text { Mean } \\
\text { score (out } \\
\text { of 5) } \\
\end{array}$ & SD \\
\hline $\begin{array}{l}\text { When I searched for information in } \\
\text { the online collocation dictionary, I } \\
\text { got the information that I needed. } \\
\text { (Percentage) }\end{array}$ & $0 \%$ & $0 \%$ & $3.84 \%$ & $73.07 \%$ & $23.07 \%$ & 4.19 & 0.49 \\
\hline $\begin{array}{l}\text { I did not have problems in analyzing } \\
\text { corpus lines. } \\
\text { (Percentage) }\end{array}$ & $\begin{array}{c}15 \\
19.23 \% \\
\end{array}$ & $\begin{array}{r}51 \\
65.38 \% \\
\end{array}$ & $11.53 \%$ & $\begin{array}{c}3 \\
3.84 \% \\
\end{array}$ & 0 & 2 & 0.69 \\
\hline $\begin{array}{l}\text { I did not have problems in analyzing } \\
\text { the online collocation dictionary } \\
\text { output. } \\
\text { (Percentage) }\end{array}$ & $3.84 \%$ & $3.84 \%$ & $3.84 \%$ & $34.61 \%$ & $53.84 \%$ & 4.30 & 1.01 \\
\hline $\begin{array}{l}\text { I have some difficulty in using the } \\
\text { corpus and/or the online dictionary } \\
\text { due to limited access to computers. } \\
\text { (Percentage) }\end{array}$ & $42.30 \%$ & $19.23 \%$ & $3.84 \%$ & $19.23 \%$ & $15.38 \%$ & 2.46 & 1.58 \\
\hline $\begin{array}{l}\text { I have some difficulty in using the } \\
\text { corpus and/or the online dictionary } \\
\text { due to time and effort spent on } \\
\text { analyzing the data. } \\
\text { (Percentage) }\end{array}$ & 0 & $11.53 \%$ & $7.69 \%$ & $53.84 \%$ & $26.92 \%$ & 3.96 & 0.91 \\
\hline $\begin{array}{l}\text { Using the corpus and/or the online } \\
\text { collocation dictionary I felt that I was } \\
\text { most likely to make meaningful and } \\
\text { noticeable improvements for my } \\
\text { writing in learning the meaning of the } \\
\text { vocabulary. } \\
\text { (Percentage) }\end{array}$ & $3.84 \%$ & $26.92 \%$ & $61.53 \%$ & $7.69 \%$ & $0 \%$ & 2.73 & 0.66 \\
\hline $\begin{array}{l}\text { Using the corpus and/or the online } \\
\text { collocation dictionary I felt that I was } \\
\text { most likely to make meaningful and } \\
\text { noticeable improvements for my } \\
\text { writing in learning to correct } \\
\text { grammar. } \\
\text { (Percentage) }\end{array}$ & $0 \%$ & $0 \%$ & $11.53 \%$ & $65.38 \%$ & $23.08 \%$ & 4.11 & 0.58 \\
\hline $\begin{array}{l}\text { Using the corpus and/or the online } \\
\text { collocation dictionary I felt that I was } \\
\text { most likely to make meaningful and } \\
\text { noticeable improvements for my } \\
\text { writing in learning to use vocabulary } \\
\text { appropriately. } \\
\text { (Percentage) }\end{array}$ & $0 \%$ & $0 \%$ & $7.69 \%$ & $46.15 \%$ & $46.15 \%$ & 4.38 & 0.63 \\
\hline $\begin{array}{l}\text { Using the corpus and/or the online } \\
\text { collocation dictionary I felt that I was } \\
\text { most likely to make meaningful and } \\
\text { noticeable improvements for my } \\
\text { writing in learning organization. } \\
\text { (Percentage) }\end{array}$ & $30.76 \%$ & $34.61 \%$ & $26.92 \%$ & $3.84 \%$ & $3.84 \%$ & 2.15 & 1.04 \\
\hline $\begin{array}{l}\text { Over all, the corpus and/or the online } \\
\text { collocation dictionary are/is a useful } \\
\text { resource for my English proficiency } \\
\text { improvement. } \\
\text { (Percentage) }\end{array}$ & $3.84 \%$ & $0 \%$ & $3.84 \%$ & $53.84 \%$ & $38.46 \%$ & 4.23 & 0.86 \\
\hline
\end{tabular}

\subsection{Future Assignment Usage}

According to the results from the post-study survey, participants generally presented a favorable attitude towards the use of WBLL materials and tools for further outside assignment usage. However, beginning with their personal English writing, 45 participants (57.69\%) couldn't decide and 24 participants (30.76\%) disagreed with the use of the WBLL materials and tools, which leaves the category bearing a mean score of 2.69. On the 
Mashhadizadeh, D., \& Rezvani, E.

contrary, in the case of writing papers for other courses and future academic writing, the mean scores of 3.96 and 4.26 respectively, show a positive trend towards the use of the WBLL materials and the tools, as in both cases 45 participants (57.69\%) agreed with the concept of using the approach in the future.

Moreover, 60 participants (76.92\%) agreed and 15 participants (19.23\%) strongly agreed that by the passage of time, they had to come to like the materials and tools more, and just 3 participants (3.84\%) chose the option of undecided. In addition, a mean score of 4.42, with 39 participants (50\%) agreeing and 36 participants (46.15\%) strongly agreeing, showed that participants' attitude towards recommending the tools and materials to their friends is positive. Table 5 summarizes the information on the learners' attitude towards the Outside assignment usage.

Table 5

Learners' Attitude towards the Outside assignment usage

\begin{tabular}{|c|c|c|c|c|c|c|c|}
\hline & $\begin{array}{l}\text { Strongly } \\
\text { disagree }\end{array}$ & Disagree & Undecided & Agree & $\begin{array}{c}\text { Strongly } \\
\text { agree }\end{array}$ & $\begin{array}{c}\text { Mean score } \\
\text { (out of 5) }\end{array}$ & $\mathrm{SD}$ \\
\hline $\begin{array}{l}\text { I often used the corpus and/or the } \\
\text { online collocation dictionary for my } \\
\text { own English writing. } \\
\text { (Percentage) }\end{array}$ & $3.84 \%$ & $30.76 \%$ & $57.69 \%$ & $7.69 \%$ & $0 \%$ & 2.69 & 0.67 \\
\hline $\begin{array}{l}\text { I used the corpus and/or the online } \\
\text { collocation dictionary when writing } \\
\text { papers for other courses. } \\
\text { (Percentage) }\end{array}$ & $0 \%$ & $0 \%$ & $23.07 \%$ & $57.69 \%$ & $19.23 \%$ & 3.96 & 0.66 \\
\hline $\begin{array}{l}\text { As I used more the corpus and/or the } \\
\text { online collocation dictionary, I had } \\
\text { come to like them more. } \\
\text { (Percentage) }\end{array}$ & $0 \%$ & $0 \%$ & $3.84 \%$ & $76.92 \%$ & $19.23 \%$ & 4.15 & 0.46 \\
\hline $\begin{array}{l}\text { I will use the corpus and/or the online } \\
\text { collocation dictionary for my } \\
\text { academic English writing in the } \\
\text { future. } \\
\text { (Percentage) }\end{array}$ & $0 \%$ & $0 \%$ & $7.69 \%$ & $57.69 \%$ & $34.61 \%$ & 4.26 & 0.60 \\
\hline $\begin{array}{l}\text { I will recommend using the corpus } \\
\text { and/or the online collocation } \\
\text { dictionary for writing to my friends. } \\
\text { (Percentage) }\end{array}$ & $0 \%$ & $0 \%$ & $3.84 \%$ & $50 \%$ & $46.15 \%$ & 4.42 & 0.57 \\
\hline
\end{tabular}

\section{Discussion}

According to the results of the current study, learners' attitude towards the WBLL approach was positive in the areas of the helpfulness of the approach, and improvement in their confidence and writing proficiency, as well as the sub-field of word phrase. However, in the case of word phrase usage, the online collocation dictionary, which was an essential tool in the approach, didn't succeed in satisfying the learners' expectations. These results are in line with those of the study done by Son 2007, in which the learners referred to the WBLL approach as a helpful method for successful learning of the language. Moreover, in a similar study done by Ayres 2010 on CALL, learners stated a highly appreciated face validity for the computer assisted learning methods, which can be also applied to the WBLL approach. Results from Talebinezhad and Abarghoui (2013) further approve such position. However, the usefulness of the approach varies according to the nature of the tasks presented to the students; as in this current study, the online collocation dictionary did not comply with the word-phrase usage capabilities of the online corpora.

In the area of learners' attitude towards WBLL tools, learners reflected a preference for the online collocation dictionary over the online corpus, as the online dictionary was easier to manage in numerous ways, including analyzing the output and searching technique. This is in compliance with that of the study by Nam, D. (2010), in which the learners revealed a lack of interest to use the corpus as an online tool due to its insufficiencies and difficulties in analyzing the output. In that study, the learners preferred the thesaurus, which 
can resemble the online collocation dictionary in the current study.

Regarding the issue of future assignment usage, learners' attitude towards using the approach for further assignments, apart from personal English writings, was positive. The subjects also stated that they had come to like the tools and the approach as time passed, and they would recommend the tools and materials to their peers. These findings are in accordance with those of the Son (2007), in which the learners agreed to have WBLL materials as a daily part of other courses. However, the results from Nam, D. (2010) revealed that students would not use the corpus for their writings anymore, or they would not recommend using it to their friends. This was due to the fact that in that study, the online resources were limited to just the online corpora, which is the source of difficulty for most of the learners even in the current study. Therefore, considering the fact that in this study, not only an online corpus but also an online dictionary was used as the online resources, the user-friendliness of the online dictionary could be referred to as the factor which caused satisfaction among the participants.

\section{Conclusion}

World Wide Web has provided Language teachers and learners with numerous opportunities to further their teaching and learning experience. Applying WBLL approach to the context of the language teaching can complement the classroom-based approaches, providing the teacher with time and flexibility needed to direct a more comprehensive task. In addition, the learners can enjoy learning more than what the scope of the classroom allows for, which in turn derives a higher level of satisfaction among them. In this study, attitude of the learners towards WBLL approach, tools, and materials was investigated and it was revealed that the shift to WBLL approach is mostly welcome by the learners, especially when the tools and materials are easy enough to be handled and analyzed. Therefore, in order to optimize the WBLL experience, teachers should try to design the courses and provide the materials and resources that are comprehensible and manageable for the learners. This will surely contribute to the widespread use of such methodology, and the freshness of the concept will appeal to the whole community of the language teachers and learners.

\section{References}

Amirsheibani, M., \& Iraji, M. (2014). CALL and teaching writing: Language teachers' attitude, an Iranian survey. Procedia - Social and Behavioral Sciences, 98, 258-266. http://dx.doi.org/10.1016/j.sbspro.2014.03.415

Ayres, R. (2002). Learner attitudes towards the use of CALL. Computer Assisted Language Learning, 15(3), 241-249. http://dx.doi.org/10.1076/call.15.3.241.8189

Azizinezhad, M., \& Hashemi, M. (2013). A look at the status of computer assisted language learning and its applications. Procedia - Social and Behavioral Sciences, 93, 121- 124. http://dx.doi.org/10.1016/j.sbspro.2013.09.163

Dashtestani, R. (2012). Barriers to the implementation of CALL in EFL courses: Iranian EFL teachers' attitudes and perspectives. The Jalt CALL Journal, 8(2), 55-70.

Dashtestani, R. (2014). EFL teachers' knowledge of the use and development of computer-assisted language learning (CALL) materials. Teaching English with technology, 14(2), 3-26.

Felix, U. (2001). Research: Absolutely worth the effort! In U. Felix (Ed.), Beyond Babel: Language learning online (pp. 299-365). Melbourne: Language Australia.

Gruber-Miller, J., \& Benton, C. (2001). How do you say "MOO" in Latin? Assessing student learning and motivation in beginning Latin. CALICO Journal, 18(2), 305-338.

Jalali S., \& Dousti, M. (2014). Attitudes of Iranian EFL learners towards CALL: The effect of treatment length investigated. Malaysian Journal of ELT Research, 10(1), 46-62.

Kung, S. C., \& Chuo, T. W. (2002). Students' perceptions of English learning through ESL/EFL Websites. The Electronic Journal for English as a Second Language, 6(1).

Mosquera, F. M. (2001). CALT: Exploiting Internet resources and multimedia for TEFL in developing countries. Computer Assisted Language Learning, 14(5), 461-468. http://dx.doi.org/10.1076/call.14.5.461.5768 
Mashhadizadeh, D., \& Rezvani, E.

Murray, D. E., \& McPherson, P. (2004). Using the web to support language learning. Sydney: National Centre for English Language Teaching and Research. Teaching with new technology series.

Nam, D. (2010). Productive vocabulary knowledge and evaluation of ESL writing in corpus-based language learning. (Doctoral dissertation). Indiana University Bloomington.

Rahimi, M., \& Hosseini, K. S. F. (2011). The impact of computer-based activities on Iranian high-school students' attitudes towards computer-assisted language learning. Procedia Computer Science, 3, 183-190. http://dx.doi.org/10.1016/j.procs.2010.12.031

Son, J. B. (2005). Making Web-based language learning meaningful. Paper presented at the Second International Conference on Pedagogies and Learning, University of Southern Queensland, Toowoomba, Australia.

Son, J. B. (2007). Learner experiences in web-based language learning. Computer Assisted Language Learning, 20(1), 21-36. http://dx.doi.org/10.1080/09588220601118495

Son, J. B. (2008). Using web-based language learning activities in the ESL classroom. International Journal of Pedagogies and Learning, 4(4), 34-43. http://dx.doi.org/10.5172/ijpl.4.4.34

Stepp Greany, J. (2002). Student perceptions on language learning in a technological environment: Implications for the new millennium. Language Learning \& Technology, 6(1), 165-180.

Talebinezhad, M. R., \& Aziz Abarghoui, M. (2013). The Iranian high school students' attitude toward CALL and the use of CALL for EFL receptive skills. Theory and Practice in Language Studies, 3(2), 329-337. http://dx.doi.org/10.4304/tpls.3.2.329-337

Yoon, H., \& Hirvela, A. (2004). ESL student attitudes toward corpus use in L2 writing. Journal of Second Language Writing, 13, 257-283. http://dx.doi.org/10.1016/j.jslw.2004.06.002 